\title{
Foraminifera and Late Cenomanian-Turonian biostratigraphy of the northern palaeobiogeographic district of Western Siberia
}

\author{
Vera Podobina \\ Tomsk State University, 36 Lenin Ave., Tomsk, 634050 Russia; e-mail: podobina@ggf.tsu.ru
}

\begin{abstract}
The study of 114 core samples from seven borehole sections of the Van-Eganskaya area in the central part of Western Siberia yielded sufficient data to investigate the Late Cenomanian-Turonian foraminifers, palaeoenvironments, and the Late Cenomanian-Turonian biostratigraphy of this poorly studied area. Two Late Cenomanian foraminifer zones were established, viz. a (lower) Saccammina micra - Ammomarginulina sibirica Zone and an (upper) Trochammina wetteri tumida - Verneuilinoides kansasensis Zone. They reflect changes in the species composition of the foraminifer assemblages and lithology of the host rocks of the Uvatskian Horizon. In the lower part of the upper zone, beds with Gaudryinopsis nanushukensis elongatus are present. The changes in the species composition and lithology of the upper Cenomanian resulted from water-depth variations during the Boreal transgression. Two distinct assemblages and two homonymous zones, viz. the (lower) Gaudryinopsis angustus and the (upper) Pseudoclavulina hastata zones occur in the Turonian clayey cap-rocks of the superimposed Kuznetsovskian Horizon. Comparison of the Late Cenomanian-Turonian assemblages from the West-Siberian and Canadian provinces of the same Arctic palaeobiogeographical realm shows that the West-Siberian species are the same as, and closely related to, Canadian taxa, along with geographical subspecies. This comparison allows a detailed correlation, which results in a precise dating of the foraminifer zones.
\end{abstract}

Key words: Foraminifera, biostratigraphy, Upper Cenomanian, Turonian, Western Siberia

\section{Introduction}

Cenomanian deposits of almost the whole territory of Western Siberia are represented by continental facies, which yield mainly sporeand-pollen complexes, leaves and charred plant remains. The late Cenomanian-Turonian foraminifers from the northern part of this region (the Tazovskaya and Purpeyskaya areas) have been described by Podobina \& Tanachova (1967). Their study resulted in the recognition of two Late Cenomanian microfaunal zones: a (lower) Verneuilinoides kansasensis Zone and an (upper) Trochammina wetteri - T. subbotinae Zone.
The present contribution presents the results of a study of the late Cenomanian foraminifers from the top of the Uvatskian Horizon within the Van-Eganskaya area, which is situated north of the $\mathrm{Ob}^{\prime}$ River in the northern palaeobiogeographic district of Western Siberia (Figs. 1 and 2). The northern district is one of five palaeobiogeographic districts of Western Siberia named according to the cardinal points (Podobina, 1995).

Both Late Cenomanian zones previously studied are characterised by an almost identical composition, and therefore they are combined in the present contribution into one single zone, the Trochammina wetteri tumida - 
Verneuilinoides kansasensis Zone. Lithologically it consists of dark-grey, almost black clays of $10-15 \mathrm{~m}$ thick, and it is confined to the top of the Uvatskian Horizon (Podobina, 2000, $2009,2012 a, c)$. It has been ascertained that the species composition of this new zone of the West-Siberian Province is much similar to that of the Canadian Province (northern Canada and northern Alaska) of the Arctic palaeobiogeographical realm (Tappan, 1962; Wall, 1967, 1983; Podobina, 1995, 2000).

Following the study of Podobina \& Tanachova (1967) of the Cenomanian foraminifers and the biostratigraphy on the territory of the Tazovskaya and Purpeyskaya areas, no studies of the Cenomanian foraminifers from this part of Western Siberia (the Uvatskian Horizon) have been published. Zakharov et al. (1989) reported the discovery of marine Cenomanian deposits based on the discovery of mollusks in the northern part of Siberia (the Nizhnyaya Agapa River, north-east of the town of Dudinka). The occurrence of the Upper Cenomanian was documented by finds of the bivalves Inoceramus pictus Sowerby and that of the Lower Turoni-

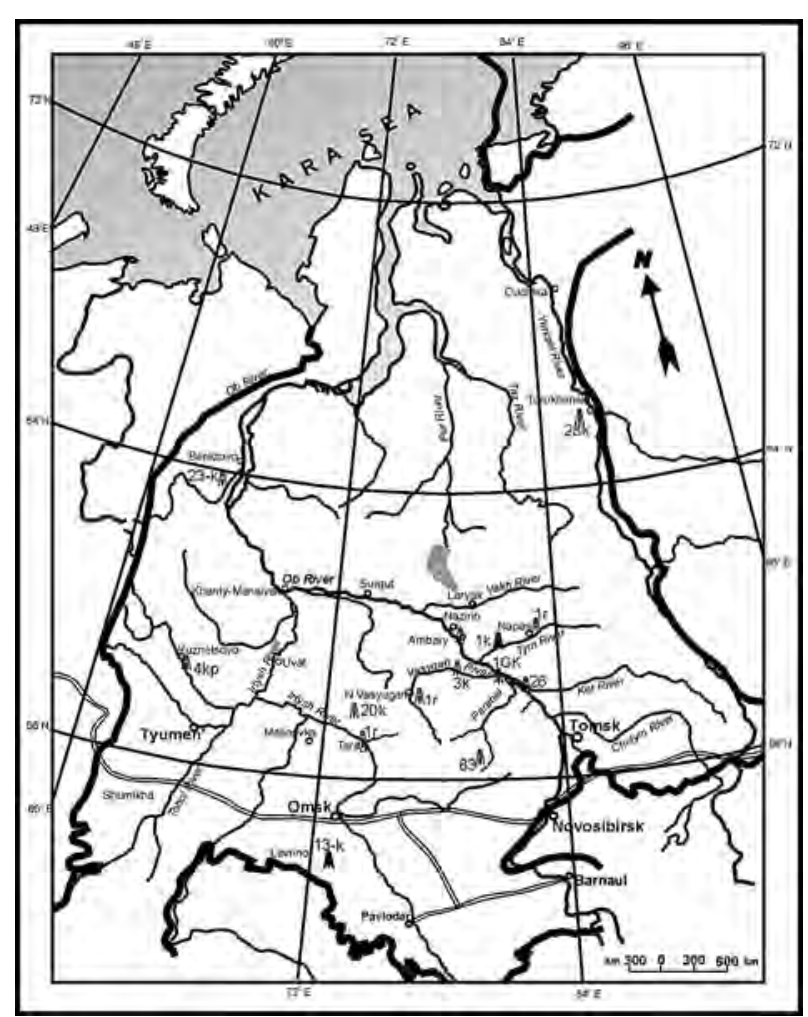

Fig. 1. Location of the studied boreholes in Western Siberia. an by I. labiatus (Schlotheim); no microfaunal forms or micropalaeontological remains were mentioned in their study.

The new microfauna from the Van-Eganskaya area gives the possibility to establish a detailed Late Cenomanian biostratigraphical framework. This is highly significant, because the Late Cenomanian sediments are good reservoir rocks for proven economical accumulations of hydrocarbons. Not less important is the investigation of the biostratigraphy of clayey cap rocks, which formed a seal for the hydrocarbons in the Van-Eganskaya and other areas. It is precisely the overlying Turonian dark-grey clays of the Kuznetsovskian Horizon that acted as the main cap rock. Foraminifer assemblages well known from Western Siberia were recov-

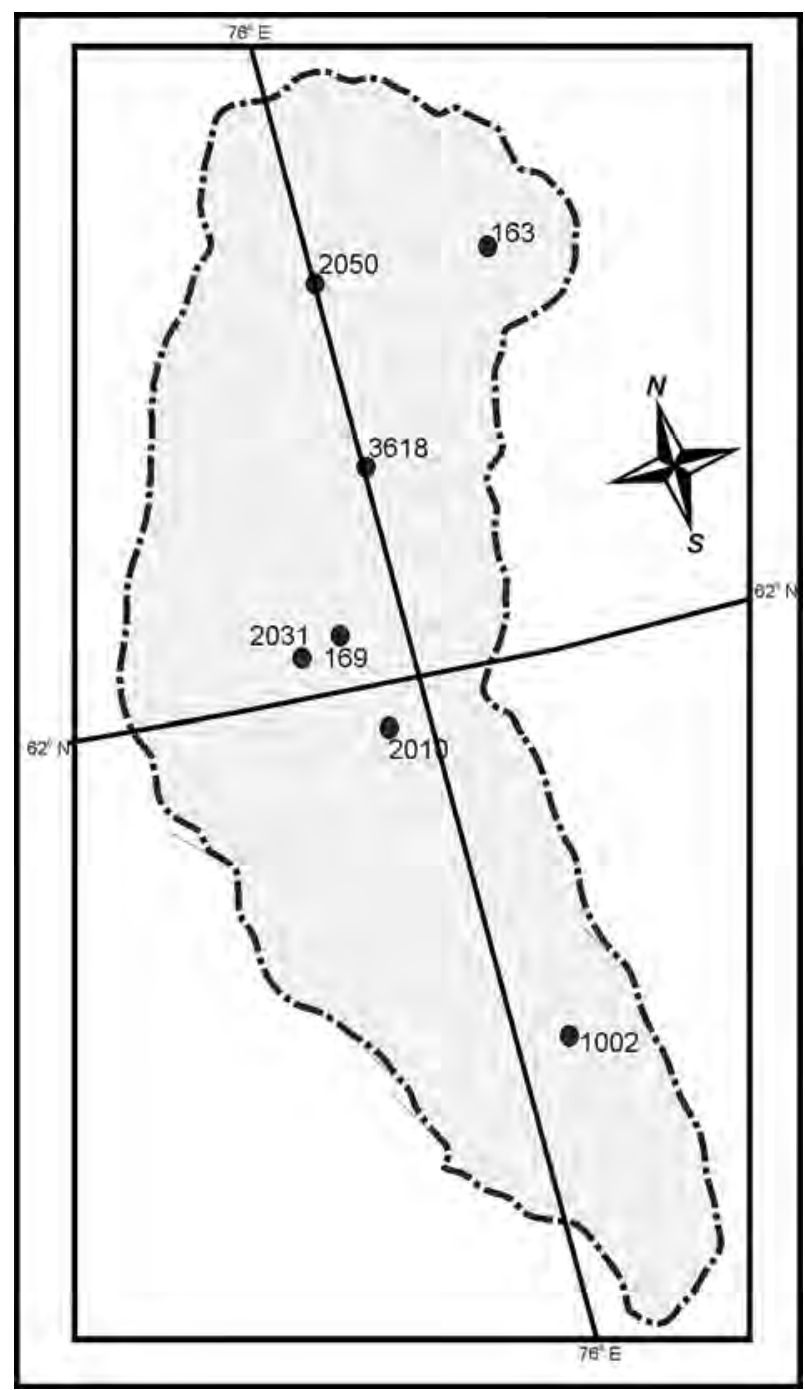

Fig. 2. Location of the studied boreholes in the Van-Eganskaya area. 
Table 1. Schematic biostratigraphy of the Late Cenomanian-Turonian deposits of the West-Siberian and Canadian provinces of the Arctic realm.

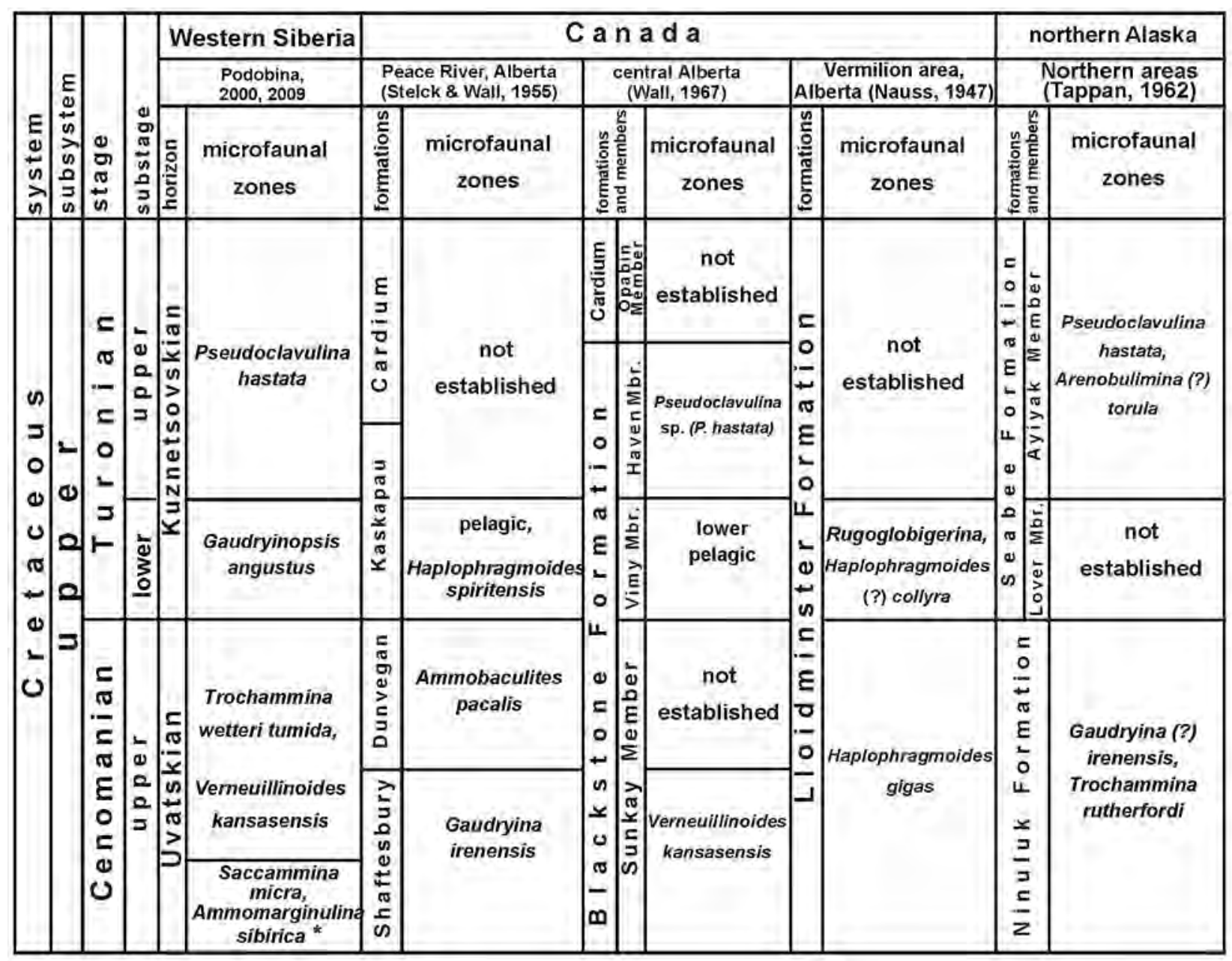

\section{${ }^{*}$ Note: Analogues of West-Siberian upper Cenomanian lower zone Saccammina micra - Ammomarginulina sibirica have not yet been traced in the Canadian province.}

ered from these clays in two sections (boreholes 1002, 2031): the (lower) Gaudryinopsis angustus Assemblage and the (upper) Pseudoclavulina hastata Assemblage. The beds containing these assemblages correspond to the Early and Late Turonian zones respectively, and have the same names (Podobina, 1975, 1989, 2000, 2009, $2012 b)$. In the section of borehole 1002, numerous planktonic foraminifers of the genus Hedbergella occur in the Early Turonian deposits. Similar forms designated as 'pelagic' have been identified by Wall (1967) from the Early Turonian of the Canadian Province (Table 1).

The new data on the microfauna, in particular the foraminifers, allow to subdivide the up- per Cenomanian into two microfaunal zones, and to correlate these with contemporaneous zones of the Canadian Province. The West-Siberian Province and the Canadian Province belong both to a common palaeobiochore: the Arctic palaeobiogeographical realm.

\section{Material and methods}

The microfaunal analysis shows that microfossils occur in 114 out of 124 samples. The samples were collected from boreholes 163, 169, 1002, 2010, 2031, 2050 and 3618 drilled in the Van-Eganskaya area. Most of the samples 
of Turonian and late Cenomanian age were collected from boreholes 1002 (16 samples) and 2031 (34 samples). In all sections, except for that of borehole 163, foraminifer assemblages of two zones and beds of the Upper Cenomanian have been found for the first time.

They provided detailed information regarding the late Cenomanian-Turonian foraminifers, their sedimentary environments, and the biostratigraphical framework of this relatively poorly studied area. The rocks with the foraminifer assemblages are lithologically almost uniform grey silty sandstones. The foraminifer assemblages have a low diversity and are mainly represented by poorly preserved agglutinated tests with coarse and medium fine quartz grains.

Until now, two Turonian foraminifer zones have been reported in several monographs (Podobina, 1975, 1989, 2000, 2009, 2012b). The sections of boreholes 169, 2010, 2050 and 3618 are less complete: they do not comprise Turonian zones, and the assemblages represent only two Late Cenomanian zones; the upper zone - of Late Cenomanian age - occurs only in borehole 163. Tables 2 and 3 present the boundary depths of all recognised Late Cenomanian and Turonian (boreholes 1002, 2031) zones and beds.

The late Cenomanian fossil debris is dominated by foraminifer tests, which occur in most of the samples of the boreholes under study. Rock samples collected from the upper part of the Uvatskian Horizon consist mainly of grey siltstones and sandstones with interbeds of dark-grey clays. Together with the foraminifer microfauna, amber fragments and charred woody fossils occur. Silicified brown pellets (oolites), and pyritised structures of various shapes are often present.

The foraminifer assemblages include agglutinated quartz-siliceous tests and rarely secreted-calcareous tests, along with their pseudomorphs (silicified casts). Changes in the foraminifer assemblage composition and lithology result from constant tectonic movements in the upper part of the Uvatskian Horizon.

In some sections (boreholes 2010, 2050 and 3618), sparse pseudomorphs of the genus
Gaudryinopsis and coarse-grained forms of the genera Haplophragmoides, Ammoscalaria and Trochammina are present in the lower part of the upper Trochammina wetteri tumida - Verneuilinoides kansasensis Zone. Scanty silicified casts of the secreted calcareous tests of rotaliids and buliminids along with ostracod casts are also recovered from a few samples. This appears indicative for a shallowing of the basin in the area of boreholes 3618 (depth range 997.3-994.3 m), 2010 (972.0-971.0 m), and 2050 (1024.0 m). In contrast, basin deepening is documented by the foraminifers (beds with Gaudryinopsis nanushukensis elongatus) and the lithology in the sections of boreholes 1002 (983.5-981.1 m), 2031 (979.5-975.9 m), and 169 (855.6 m).

Among the abundance of foraminifer species recovered from the samples of the seven borehole sections, some species and geographical subspecies are distinguished which had not been recorded previously from the northern part of Western Siberia. Among them are nine late Cenomanian species described recently in detail by the present author (Podobina, 2012a,c): Trochamminoides ivanetzi Podobina, Labrospira rotunda Podobina, Haplophragmoides variabilis Podobina, Haplophragmium ivlevi Podobina, Ammoscalaria senomanica Podobina, Ammomarginulina sibirica Podobina, Flabellammina acuminata Podobina, Spiroplectammina longula Podobina, and Bolivinopsis perparous Podobina (Plates I-III). In addition, three late Cenomanian geographical subspecies were established by the present author: Gaudryinopsis nanushukensis Tappan subsp. elongatus Podobina, Trochammina wetteri Stelck et Wall subsp. tumida Podobina, and Trochammina subbotinae Zaspelova subsp. mutabila Podobina (Plate IV). Their taxonomical descriptions were presented by Podobina $(2012 \mathrm{a}, \mathrm{c})$.

Secreted calcareous foraminifers are rarely present in the samples, and among them only one new species, Cibicides mirus Podobina, and two geographical subspecies, Anomalinoides frankei (N. Bykova) subsp. nitidus Podobina and Cibicidoides kerisensis Vassilenko subsp. applanatus Podobina, are for the first time distinguished in the northern palaeobiogeographic district of Western Siberia (Podobina, 2012a,c). 
Table 2. Lithology and Late Cenomanian/Turonian foraminifer zones of borehole 1002 in the Van-Eganskaya area.

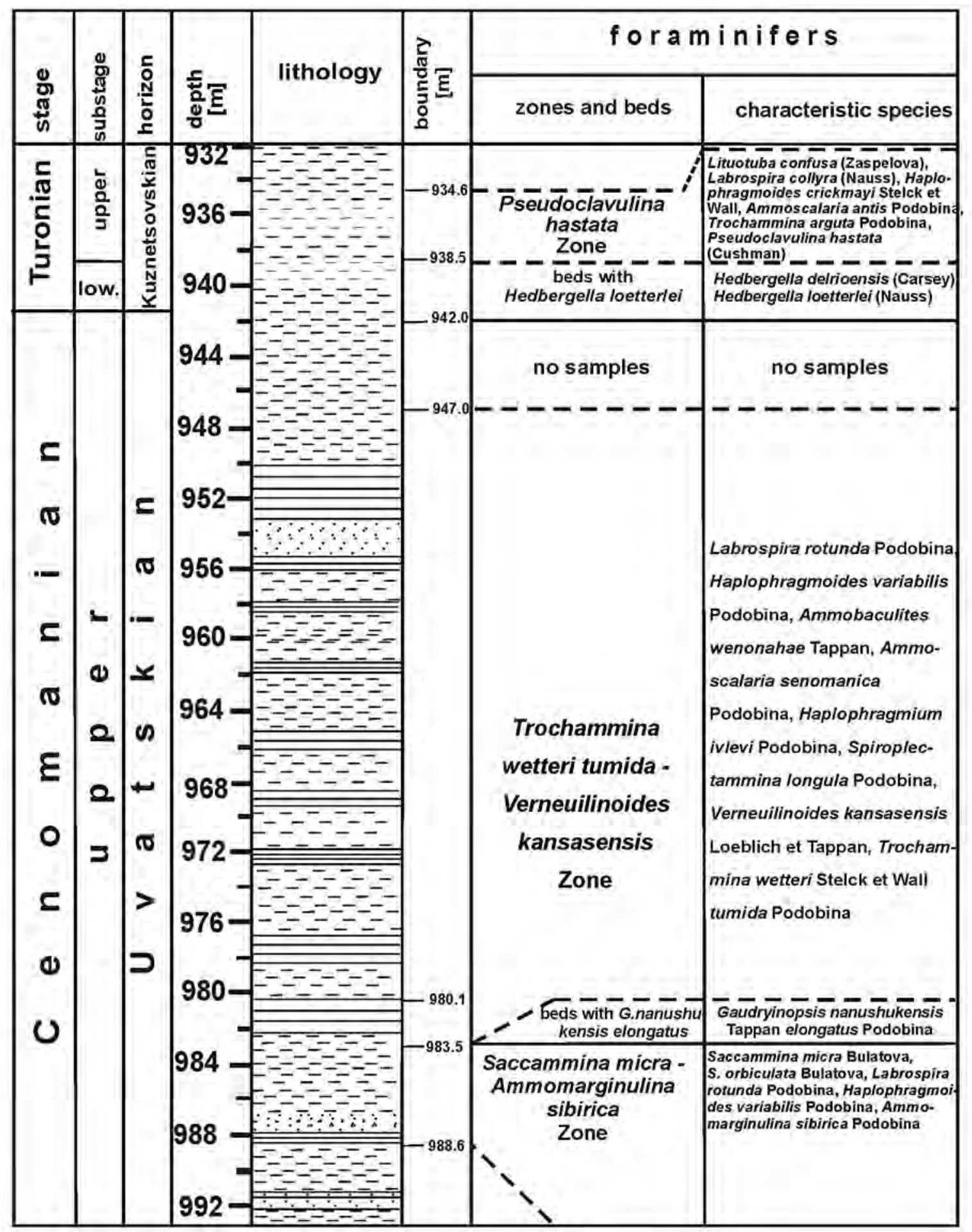

\section{Legend:}
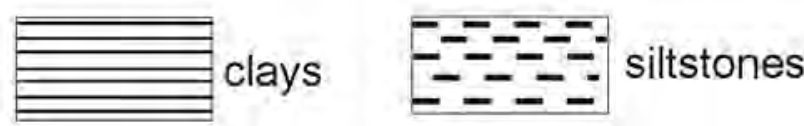
Table 3. Lithology and Late Cenomanian/Turonian foraminifer zones of borehole 2031 in the Van-Eganskaya area.

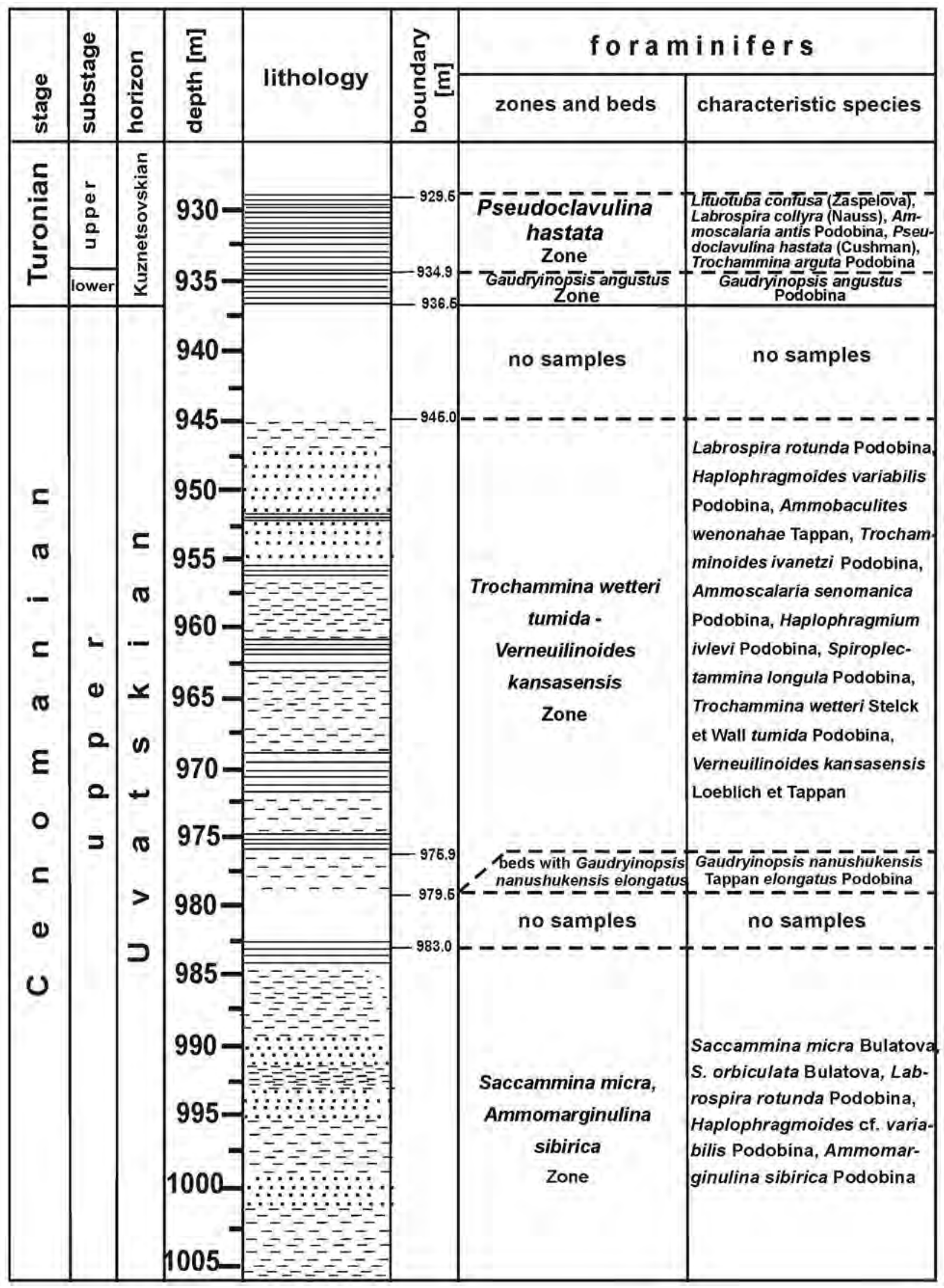




\section{Late Cenomanian biostratigraphy in the Van-Eganskaya area (Uvatskian Horizon)}

The detailed zonation of the deposits within the seven borehole sections was carried out on the basis of changes in the systematic composition of the foraminifer assemblages and the lithology; as a result, two foraminifer zones could be recognised in the Upper Cenomanian. The (lower) Saccammina micra - Ammomarginulina sibirica Zone comprises frequent interbeds with primitive agglutinated foraminifers of the genera Rhabdammina, Psammosphaera, Saccammina, Hyperammina, and Crithionina. Therefore, the name of the species Saccammina micra Bulatova is here introduced into the denomination of the integrated assemblage of this zone. The assemblage consisting of primitive tests includes a variety of species of the genus Saccammina together with sparse species of the Rhabdammina, Psammosphaera, Hyperammina, Crithionina and other genera. Among the more complicated genera, several representatives of two families of the superfamily Haplophragmiidea were encountered: the genera Labrospira and Haplophragmoides of the Haplophragmoididae family and the genera Ammomarginulina, Ammoscalaria and Ammobaculites of the Haplophragmiidae family. In the lower zone, the agglutinated tests are accompanied by sparse secreted calcareous genera (hyaline by their microstructure): Valvulineria, Eponides, Cibicides, Cibicidoides, Anomalinoides, Gavelinella, Bolivina, Praebulimina and Heterohelix.

The systematic composition of the foraminifer assemblage of the upper, Trochammina wetteri tumida - Verneuilinoides kansasensis Zone is characterised by a more constant species composition, and by the almost complete absence of interbeds with primitive tests. In the clayey rocks of the bottom part of this zone, beds with Gaudryinopsis nanushukensis elongatus are present, and they contain, along with the index Gaudryinopsis nanushukensis Tappan elongatus Podobina, species such as Labrospira rotunda Podobina, Haplophragmoides variabilis Podobina, Ammoscalaria senomanica Podobina, Trochammina wetteri Stelck et Wall tumida
Podobina, and Verneuilinoides kansasensis Loeblich et Tappan (Tables 2 and 3).

Based on the vertical distribution of the foraminifer species within the upper part of the Uvatskian Horizon, two zones are distinguished: the (lower) Saccammina micra - Ammomarginulina sibirica Zone, and the (upper) Trochammina wetteri tumida - Verneuilinoides kansasensis Zone.

\subsection{The lower Saccammina micra - Ammomarginulina sibirica Zone}

In the lower part of the zone, interbeds with primitive foraminifers (Psammosphaera, Saccammina, Crithionina, Hyperammina, etc) are frequent. In the upper part of the zone, the number of interbeds with species of the superfamily Haplophragmiidea increases. Moreover, sparse tests of the secreted calcareous genera (with the hyaline microstructure) Valvulineria, Eponides, Gavelinella, Cibicides, Cibicidoides, Praebulimina, Bolivina and Heterohelix occur. The overall assemblage of this zone includes the species Psammosphaera laevigata White, Hippocrepinella oblongiovalis Bulatova, Saccammina micra Bulatova, S. orbiculata Bulatova, S. scabra Bulatova, S. testideformabilis Bulatova, $S$. sphaerica (M. Sars), Crithionina dubia Bulatova, Thurammina papillata Brady, Hyperammina aptica (Dampel et Mjatliuk), Reophax inordinatus Young, Trochamminoides ivanetzi Podobina, Labrospira rotunda Podobina, Haplophragmoides variabilis Podobina, Ammobaculites wenonahae Tappan, Ammomarginulina sibirica Podobina, Ammoscalaria senomanica Podobina, Flabellammina acuminata Podobina, Trochammina wetteri Stelck et Wall tumida Podobina, Eponides morani Tappan, Cibicidoides kerisensis Vassilenko applanatus Podobina, and Heterohelix globulosa (Ehrenberg) (Plates I-IV).

\subsection{The upper Trochammina wetteri tumida - Verneuilinoides kansasensis Zone}

The 10-15 m thick beds with the updated foraminifer assemblage with Gaudryinopsis 
nanushukensis elongatus in its lower part are assigned to this zone. These beds are recognised in boreholes 169, 1002 and 2031 by the occurrence of the genus Gaudryinopsis and sparse specimens of the genera Labrospira, Haplophragmoides, Ammoscalaria,Trochammina, Verneuilinoides; these latter species are useful for regional and interregional correlations.

The beds with this foraminifer assemblage in the lower part of the upper zone correspond to a wider spreading and deepening of the basin during the Boreal transgression. Therefore, the tests with elaborate test architecture of the genus Gaudryinopsis, and other genera of the Ataxophragmiida order evolved under changed and more favourable environmental conditions.

A frequent alternation of the layers with foraminifer test of diverse type and species composition is present in the upper zone. However, mostly coarse-grained species of the genera Labrospira, Haplophragmoides, Ammobaculites, Trochammina, Verneuilinoides, etc. are found in this zone. The integrated assemblage of the upper Trochammina wetteri tumida - Verneuilinoides kansasensis Zone includes the species Labrospira rotunda Podobina, Haplophragmoides variabilis Podobina, Ammobaculites wenonahae Tappan, Haplophragmium ivlevi Podobina, Ammoscalaria senomanica Podobina, Spiroplectammina longula Podobina, Trochammina wetteri Stelck et Wall tumida Podobina, Verneuilinoides kansasensis Loeblich et Tappan, Gavelinella awunensis Tappan, and Cibicidoides kerisensis Vassilenko applanatus Podobina.

It is worthwhile to mention that in the rocks of this zone pseudomorphs of sparse calcareous forms of various colours are present. At some levels of the seven boreholes, also brown globes and sticks, and sometimes pyritised internal casts and silicified pseudomorphs of foraminifers occur. Ostracod internal casts and radiolarian skeletons are also present; Cenodiscus and Cenosphaera dominate the radiolarian assemblage. Only at a depth of $945.10 \mathrm{~m}$ in borehole 2031, well-preserved foraminifer tests of the upper zone are found. The layers containing such tests are predominantly darkgrey, compact clays of the upper part of the Uvatskian Horizon. In the other borehole sec- tions and in the above-mentioned section 2031 (at depths below $945.10 \mathrm{~m}$ ), the agglutinated foraminifer tests were for the most part coarsegrained and poorly preserved (Tables 2 and 3 ).

\section{Turonian}

In the description of the established Turonian assemblages, the denomination of one species, Hedbergella loetterlei (Nauss), is supposed to raise a discussion. The reason because this species is considered outside of Russia as Archaeoglobigerina cretacea (d'Orbigny, 1840) and $H$. loetterlei (Nauss) as its junior synonym. I do not hold this viewpoint, however, and I consider them as two different species. The species $H$. loetterlei resembles $A$. cretacea neither morphologically, nor in occurrence: $H$. loeterllei is a simple, smaller form, with less inflated globular chambers slightly overlapping, with simple umbilical apertures, and a less undulated peripheral margin. Besides, it is known from the Lower Turonian of northern Canada (Wall, 1967), northern Alaska (Tappan, 1962) and the northern palaeobiogeographic district of Western Siberia (Podobina, 2009, 2012b). Moreover, this species seems characteristic of the Lower Turonian of the Arctic realm, whereas finds of A. cretacea are mainly recorded in the provinces of the Boreal and Tethyan realms. Hence, this species will be named $H$. loetterlei (Nauss) in the following.

In boreholes 1002 and 2031, foraminifer taxa were distinguished which are typical for the Turonian deposits (the Kuznetsovskian Horizon) of Western Siberia and which have commonly been recorded from the Turonian marine rocks of this region (Subbotina, 1964; Podobina, 1975, 1989, 2000, 2009, 2012b). Two zones were established on the basis of foraminifers: a (lower) Gaudryinopsis angustus zone (early Turonian), in the lower part of which beds with Hedbergella loetterlei occur, and an (upper) Pseudoclavulina hastata zone of late Turonian age. This latter zone is characterised by many other late Turonian foraminifer species that are widely-spread over almost all sections in Western Siberia. No new species have been found in the Turonian of the sections under study. 
The stratigraphical position of the Turonian zones and the characteristics of their assemblages have been described by Podobina $(2000,2009,2012 b)$ and are presented here in Tables 2 and 3. Plates V and VI illustrate the characteristic foraminifer species of the Early and Late Turonian.

\subsection{The Lower Turonian Gaudryinopsis angustus Zone}

The foraminifer species characteristic of the Lower Turonian occur in two samples from borehole 1002. In the lower sample (depth $942.0 \mathrm{~m}$ ), two species of planktic foraminifers were identified, viz. Hedbergella loetterlei (Nauss) and H. delrioensis (Carsey). These species are relatively frequent: over 30 specimens were found.

In the upper sample (from a depth 938.5 $\mathrm{m})$, the Gaudryinopsis angustus assemblage of early Turonian age is abundant and diverse in species composition. The following species were identified: Psammosphaera laevigata White, Hyperammina aptica (Dampel et Mjatliuk), Labrospira collyra (Nauss), L. fraseri (Wikenden) stata Podobina, Haplophragmoides rota Nauss subsp. sibiricus Zaspelova, $H$. crickmayi Stelck et Wall, Trochammina wetteri Stelck et Wall, Trochammina subbotinae Zaspelova, Pseudoclavulina hastata (Cushman), and Gaudryinopsis angustus Podobina. The most frequent are the genera Labrospira, Haplophragmoides and Trochammina, but the presence of the index species Gaudryinopsis angustus Podobina defines the age and stratigraphical position of the homonym zone.

The other Early Turonian section is that of borehole 2031, which is located in the centre of the Van-Eganskaya area. In two samples from the Early Turonian Gaudryinopsis angustus Zone (depth range 936.5-934.9 m), a characteristic foraminifer assemblage with Gaudryinopsis angustus occurs. Its species composition is similar to that in borehole 1002.

\subsection{The Upper Turonian Pseudoclavulina hastata Zone}

The Pseudoclavulina hastata Zone of late Turonian age is present in the overlying beds of borehole 1002 (depth 938.5-934.6 m). This zone is characterised by an assemblage of the same name consisting of the species Psammosphaera laevigata White, Lituotuba confusa (Zaspelova), Labrospira collyra (Nauss), Haplophragmoides rota Nauss subsp. sibiricus Zaspelova, H. crickmayi Stelck et Wall, Ammoscalaria antis Podobina, Trochammina wetteri Stelck et Wall, Textularia anceps Reuss, Trochammina subbotinae Zaspelova, T. arguta Podobina, and Pseudoclavulina hastata (Cushman).

The same assemblage is also present in borehole 2031 at a depth of 934.9-929.5 m. The foraminifer assemblage of this zone was studied on the basis of a sample from $929.1 \mathrm{~m}$ deep and compared with the assemblage described above from borehole 1002 (Tables 2 and 3). The species composition of the assemblage in borehole 2031 is: Rhizammina indivisa Brady, Psammosphaera laevigata White, Psammosphaera fusca Schultze, Hyperammina aptica (Dampel et Mjatliuk), Reophax inordinatus Young, Lituotuba confusa (Zaspelova), Labrospira collyra (Nauss), Labrospira fraseri (Wickenden) stata Podobina, Haplophragmoides rota Nauss subsp. sibiricus Zaspelova, Haplophragmoides crickmayi Stelck et Wall, Ammoscalaria antis Podobina, Trochammina wetteri Stelck et Wall, T. subbotinae Zaspelova, T. arguta Podobina, Recurvoidella sewellensis (Olsson) subsp. parvus Belousova, Gaudryinopsis angustus Podobina, and Pseudoclavulina hastata (Cushman). Pyritised spherules and sticks also occur. The varied species composition and good preservation of the tests suggest relatively deep-water epicontinental environment and a favourable habitat.

Although the Turonian assemblages have previously been studied from the majority of the Kuznetsovskian Horizon sections in Western Siberia, late Cenomanian foraminifer assemblages with this species composition have now been found for the first time. 


\section{Comparison of the Cenomanian- Turonian foraminifer assemblages of the Arctic palaeobiogeographical realm}

Analysis of the Cenomanian-Turonian foraminifers of the West-Siberian Province shows that their assemblages are similar to those from northern Alaska and northern Canada (the Canadian Province), all of them belonging to the Arctic palaeogeographical realm. A detailed comparison between foraminifers of this age was therefore carried out (Podobina, 1995, 2000). The species interrelations were considered: both vicarious (i.e. acting as substitutes; closely related taxa in corresponding but separate environments) and common species, as well as geographical subspecies were noted. This comparison between the Cenomanian-Turonian assemblages of Western Siberia, northern Alaska and northern Canada revealed not only a similarity in the systematic composition of foraminifers at genus and species levels in separate strata, but also in the quantitative distribution of species within sections (Nauss, 1947; Stelck \& Wall, 1955; Tappan, 1962; Wall, 1967). Moreover, the lithological characteristics (almost non-carbonated clays, siltstones, sandstones) of these two provinces are also similar (Table 1).

The Cenomanian-Turonian assemblages of Western Siberia, and the coeval foraminifers from Arctic Canada (McNeil, 1997) and the Canadian Arctic Archipelago (Wall, 1983) have also been compared. The West-Siberian foraminifer assemblages, especially the Turonian ones, differ significantly from those of the two other regions, probably because they seem to indicate deeper water.

In the Cenomanian-Turonian sections of the Canadian Arctic Archipelago, one foraminifer zone is present, viz. the Dorothia smokyensis Zone (Wall, 1983). The assemblage of this zone is significantly impoverished in diversity. Wall (1983) identified the species Pseudoclavulina sp. (in the present contribution assigned to $P$. hastata), Dorothia smokyensis Wall, Trochammina ribstonensis Wickenden and Uvigerinammina spiritensis (Stelck et Wall).
In Arctic Canada (Beaufort-Mackenzie Basin), the Late Cenomanian-Turonian Trochammina superstes Zone occurs (McNeil, 1997). The assemblage of this zone has a low species diversity; it includes, in addition to primitive taxa of the genera Bathysiphon, Saccammina, Ammodiscus and Reophax, two species of multichambered evolute tests: Evolutinella boundaryensis McNeil and Trochammina superstes McNeil. Judging from the impoverished composition and the nature of the tests, this association was developing under unfavourable conditions of a cold-water basin with low oxygen content. Secreted calcareous forms are entirely absent.

The previously established West-Siberian Late Cenomanian Verneuilinoides kansasensis Zone (now combined with the Trochammina wetteri tumida Zone) of the northern area, where the Van-Eganskaya area is located, is almost identical in its systematic composition to the Verneuilinoides kansasensis zone of the Canadian Province (Wall, 1967) (Table 1). In Canada (central Alberta) this zone was established by Wall (1967) in the lower part of the Blackstone Formation (Sunkay Member), and assigned to the Late Cenomanian on the basis of the presence of the ammonite genus Dunveganoceras. Cenomanian foraminifer assemblages of both regions consist mainly of the agglutinated quartz-siliceous tests of the genera Labrospira, Haplophragmoides, Trochammina and Verneuilinoides. It is possible that the Trochammina rutherfordi - Gaudryina (?) irenensis Zone of northern Alaska (Tappan, 1962), in which sparse specimens of Verneuilinoides kansasensis Loeblich et Tappan occur, should also be considered as chronostratigraphically equivalent. In the Van-Eganskaya area, other species (except for the usually dominating zonal Verneuilinoides kansasensis Loeblich et Tappan species) are scarce; compared to the Canadian tests of this assemblage, they are common and vicarious species or geographical subspecies (Table $1)$.

The Canadian species Trochammina rutherfordi Stelck et Wall and Gaudryina (?) irenensis Stelck et Wall are coeval vicariants for the West-Siberian T. subbotinae Zaspelova and Gaudryinopsis angustus Podobina species. The Trochammina wetteri tumida - Verneuilinoides 
kansasensis Zone from the uppermost Uvatskian Horizon is comparable with the Trochammina rutherfordi - Gaudryina (?) irenensis zone of northern Alaska (Ninuluk Formation) (Tappan, 1962). When comparing the late Cenomanian assemblages of Western Siberia with those of northern Canada and northern Alaska, the similarity of their taxonomical compositions becomes apparent. The common late Cenomanian species in the above provinces are Ammobaculites wenonahae Tappan and Verneuilinoides kansasensis Loeblich et Tappan. The West-Siberian geographical subspecies of the Canadian species are Trochammina wetteri Stelck et Wall tumida Podobina, and Gaudryinopsis nanushukensis Tappan elongatus Podobina. New Late Cenomanian species found recently in Western Siberia are principally vicariants of species from the Canadian Province.

The analysis of the Turonian assemblages of Western Siberia, northern Canada and northern Alaska also showed their distinct similarity. The West-Siberian species were compared not only with the species reported from America and Canada (Nauss, 1947; Stelck and Wall, 1955; Tappan, 1962; Wall, 1967; McNeil, 1983), but also with the Cretaceous foraminifer species kindly donated to the present author by John Wall.

The West-Siberian early Turonian assemblages of the Gaudryinopsis angustus Zone are confined to the lower Turonian part of the Kuznetsovskian Horizon, and their age is supported by finds of Inoceramus labiatus (Schlotheim) (Podobina \& Tanachova, 1967). Their species composition has much in common with that of the coeval assemblages of northern Alaska. According to Tappan's (1962) data, the Turonian foraminifers of this region occur in the Seabee Formation. In the shallow-marine facies of the Turonian deposits of both provinces, the following species with secreted calcareous tests were distinguished: Quinqueloculina sphaera Nauss, Praebulimina seabeensis (Tappan), Neobulimina albertensis (Stelck et Wall), Heterohelix globulosa (Ehrenberg) (Podobina,1989, 2000). Some Canadian species of the genus Haplophragmoides are common in Western Siberian, as, for example, $\mathrm{Ha}$ plophragmoides crickmayi Stelck et Wall and $H$. rota Nauss sibiricus Zaspelova. There are also pairs of vicarious species, viz. the West-Siberian species Gaudryinopsis angustus Podobina and the Canadian species Gaudryina (?) irenensis Stelck et Wall; species Trochammina subbotinae Zaspelova and the north-Alaskan species T. whittingtoni Tappan. As can be deduced from the above comparison, West-Siberian and north-Alaskan Turonian foraminifers have the compositional resemblance not only at the generic level, but also at the specific one. Over half of species forming the assemblages are common and vicarious.

In Canada (Alberta, Peace River), the middle part of the Kaskapau Formation is beyond any doubt confined to the Lower Turonian (Stelck and Wall, 1955). The Haplophragmoides spiritensis Zone as well as deposits carrying a 'lower pelagic' microfauna are assigned to it. In Western Siberia, the lower beds of the Kuznetsovskian Horizon are also confined to the Lower Turonian. Among the foraminifers of the Canadian Haplophragmoides spiritensis Zone some species are related to West-Siberian forms, for example, Ammobaculites pacalis Stelck et Wall is vicarious to A. tyrrelli Nauss agglutinoides Dain; A. albertensis Stelck et Wall to $A$. tuaevi Zaspelova;_Haplophragmoides hendersonensis Stelck et Wall to H. rota Nauss sibiricus Zaspelova; and Dorothia (?) kaskapauensis gracilis Stelck et Wall to Gaudryinopsis angustus Podobina. Only Trochammina wetteri Stelck et Wall is a common species for both provinces. Neobulimina albertensis (Stelck et Wall) is a characteristic species for the West-Siberian Early Turonian deposits; this species is known in Canada as Guembelitria cretaceae Cushman albertensis Stelck et Wall (Stelck and Wall, 1954). The planktonic forms, mainly of the Hedbergella and Heterohelix genera, were found in the lowermost part of the Kuznetsovskian Horizon (the northern part of Western Siberia) and in Northern Transuralia. Vasilenko (1997) found these forms on the Belyy island North of the Yamal peninsula. All these species were similar to the 'lower pelagic' microfauna from the Canadian Early Turonian zone (Wall, 1967; Podobina, 2000). In the lowermost Kuznetsovskian Horizon of borehole 1002, beds with Hedbergella loetterlei occur, corresponding to the 
'lower pelagic' zone in Alberta characterised by the species Hedbergella loetterlei (Nauss) and H. delrioensis (Carsey).

Wall (1967) reported a 'lower pelagic' microfauna from the Vimy Member of the Blackstone Formation (central Alberta) and stated that "this fauna is readily dated early Turonian by its association with the well-known index megafossils Watinoceras reesidei and Inoceramus labiatus". Hence, an early Turonian age of the Vimy Member was proved. In this member J. Wall has determined the planktonic foraminifers Hedbergella delrioensis (Carsey), H. loetterlei (Nauss), and Heterohelix globulosa (Ehrenberg).

In the Turonian deposits of the middle part of the Lloydminster Formation in eastern Alberta, the same regularity in the distribution of foraminifers was found as in Western Siberia (Nauss, 1947; Podobina, 1995). In this part of the Lloydminster Formation, along with several representatives of the genus $\mathrm{Ha}-$ plophragmoides, the agglutinated species Haplophragmoides (?) collyra Nauss was encountered, which was identified in the Turonian of Western Siberia as the genus Labrospira. Some of Canadian species are geographical subspecies or common with West-Siberian species, as, for example, Haplophragmoides rota Nauss sibiricus Zaspelova and H. crickmayi Stelck et Wall. The species Ammobaculites tyrrelli Nauss from northern Canada was identified in the Turonian deposits of Western Siberia as the geographical subspecies $A$. tyrrelli Nauss agglutinoides Dain. The West-Siberian species Gaudryinopsis angustus Podobina and the Canadian species Gaudryina (?) hectori Nauss are vicarious. The Alberta beds with the mentioned foraminifers are supposed to correspond to the early Turonian Gaudryinopsis angustus Zone of Western Siberia. In the lower part of the Lloydminster Formation, Nauss (1947) established an assemblage of planktonic foraminifers including the species Hedbergella loetterlei (Nauss), Heterohelix globulosa (Ehrenberg) and a few representatives of the Haplophragmoidea superfamily. The foraminifers were also accompanied by Inoceramus labiatus (Schlotheim), indicating an early Turonian age of this part of the Lloydminster Formation. The stratigraphical position of the beds with the above-mentioned planktonic fo- raminifers and their species composition in the Lloydminster Formation and the lower part of the Kuznetsovskian Horizon are presumably comparable. The similar beds of the 'lower pelagic' zone in the lowermost Blackstone and Kaskapau Formations (Wall, 1967) seem to correspond to the lowermost Kuznetsovskian Horizon of northern Western Siberia, where the planktonic forms occur together with the agglutinated Gaudryinopsis angustus Assemblage.

The Late Turonian Pseudoclavulina hastata Zone was established in the overlying deposits of the Kuznetsovskian Horizon of the Western Siberian Province (Podobina, 1989, 2000, 2009, $2012 b$ ). The foraminifer assemblage is somewhat similar to that of the late Turonian, but it has certain peculiarities in the species ratio. The assemblage is dominated by the genera Haplophragmoides (H. rota Nauss sibiricus Zaspelova, H. crickmayi Stelck et Wall) and Pseudoclavulina [P. hastata (Cushman)]. The quantity of species of the genus Reophax are slightly increased, and the characteristic species Ammoscalaria antis Podobina, Textularia anceps Reuss and Trochammina arguta Podobina appear in this part of the section.

The late Turonian foraminifers of the West-Siberian Pseudoclavulina hastata Zone have much in common with the coeval assemblages of northern Alaska as far as the species composition is concerned. By Tappan's (1962) data, the late Turonian foraminifers are distributed in the upper part of the Seabee Formation. Mainly agglutinated tests of the genera Saccammina, Ammodiscus, Haplophragmoides, Ammobaculites, Spiroplectammina, Trochammina, Gaudryina (Gaudryinopsis), Verneuilinoides, Arenobulimina occur among the foraminifers.

The late Turonian assemblage of the West-Siberian Pseudoclavulina hastata Zone corresponds to the coeval northern Alaskan Pseudoclavulina hastata-Arenobulimina torula Assemblage from the upper part of the zone confined to the Seabee Formation (the Ayiyak Member). In northern Alaska, the Upper Turonian was recognised by the Inoceramus cuvieri Zone (Tappan, 1962). In the northern Alaskan Pseudoclavulina hastata - Arenobulimina torula Zone, agglutinated tests of many species characteristic of the Turonian predominate. The Seabee Formation is fairly 
similar to the West-Siberian Kuznetsovskian Horizon as regards the composition and distribution of foraminifers. The north-Canadian species Reophax pepperensis Loeblich (Tappan, 1962) in the Pseudoclavulina hastata - Arenobulimina torula assemblage from the late Turonian beds is suggested by the present author to be vicarious with West-Siberian $R$. inordinatus Young; the Canadian Haplophragmoides (?) bonanzaensis Stelck et Wall is a vicariant to the Siberian Labrospira collyra (Nauss). In Western Siberia, Haplophragmoides rota Nauss sibiricus Zaspelova was distinguished as a geographical subspecies of Haplophragmoides rota Nauss; the West-Siberian Textularia anceps Reuss and the Canadian species Textularia gravenori Stelck et Wall are vicariants; the species Trochammina wetteri Stelck et Wall and Pseudoclavulina hastata (Cushman) are common.

Wall (1967) dated two overlying units (the Haven Member and the Opabin Member) of the Blackstone Formation of central and southern Alberta as late Turonian, because they contained the late Turonian pelecypod Inoceramus lamarcki and the Pseudoclavulina sp. assemblage. This latter is analogous to the Pseudoclavulina hastata - Arenobulimina torula Assemblage from northern Alaska (Tappan, 1962), and in Western Siberia to the Pseudoclavulina hastata Assemblage. The northern Alaskan assemblage has the following species in common with that of Western Siberia: Labrospira (Haplophragmoides) collyra (Nauss), L. fraseri (Wickenden) stata Podobina, and Haplophragmoides crickmayi Stelck et Wall. The unidentified species of northern Alaska, such as Pseudoclavulina sp. and Dorothia (?) sp., correspond to the West-Siberian species Pseudoclavulina hastata (Cushman) and Gaudryinopsis angustus Podobina; Trochammina rutherfordi Stelck et Wall and T. subbotinae Zaspelova are vicariants. The majority of the listed species of northern Alaska, Canada and Western Siberia are characteristic of the Late Cenomanian-Turonian deposits. In Western Siberia the species Textularia anceps Reuss is vicarious with Textularia gravenori Stelck et Wall of the Canadian Province. Such species are characteristic of the upper Turonian of both provinces. The species Trochammina diagonis (Carsey) and its Siberian vicariant T. arguta Po- dobina first appear at this stratigraphical level, but they are also characteristic of the Coniacian deposits. Noteworthy is that the extinction of species that are characteristic of Western Siberia such as Trochammina subbotinae Zaspelova and Gaudryinopsis angustus Podobina occurred in the late Turonian.

\section{Conclusions}

Seven boreholes drilled in the Van-Eganskaya area (northern palaeobiogeographic district of Western Siberia) have penetrated the Uvatskian and Kuznetsovskian Horizons (regional stratigraphic units), which are of interest, because these Cenomanian-to-Turonian stratigraphical units contain a fossil microfauna, with foraminifers in particular. The studies of 114 core samples provided much information on the late Cenomanian-Turonian foraminifers and environments, as well as on the Late Cenomanian-Turonian biostratigraphy of this still insufficiently known area.

In the Uvatskian Horizon, two Late Cenomanian foraminifer zones were established, viz. a (lower) Saccammina micra - Ammomarginulina sibirica Zone and an (upper) Trochammina wetteri tumida - Verneuilinoides kansasensis Zone. In the lowermost part of the upper zone, beds with Gaudryinopsis nanushukensis elongatus were found. The assemblage of the (lower) Saccammina micra - Ammomarginulina sibirica Zone in the Van-Eganskaya borehole sections has a species composition that differs somewhat from the assemblage from the higher stratigraphical level. The lowermost beds of this zone are characterised by the occurrence of primitive foraminifers of the genera Rhabdammina, Psammosphaera, Saccammina, Crithionina, and Hyperammina, that indicate the beginning of the late Cenomanian Boreal transgression which did not reach the $\mathrm{Ob}^{\prime}$ River.

Judging by the upward changes in the lithology and microfauna of the lower zone, an alternation of transgressive and regressive cycles occurred during the development of the late Cenomanian marine Arctic Basin. This is particularly clear in the lower, Saccammina micra-Ammomarginulina sibirica Zone, where the 
beds with primitive forms alternate with beds containing coarse-grained tests of relatively evolved genera of the Haplophragmoididae (such as Labrospira and Haplophragmoides) and Haplophragmiidae families (such as Ammomarginulina, Flabellammina, Ammobaculites and Haplophragmium).

The Trochammina wetteri tumida - Verneuilinoides kansasensis Assemblage of the upper zone is characterised by an alternation of coarse- and middle-grained agglutinated tests, which are systematically almost uniform in all seven borehole sections. They are mostly the above-mentioned representatives of the Haplophragmiidae superfamily along with species of the Ataxophragmiida order: Gaudryinopsis nanushukensis Tappan elongatus Podobina, Trochammina wetteri Stelck et Wall tumida Podobina, and Verneuilinoides kansasensis Loeblich et Tappan).

In one section (borehole 2031, depth 945.0 $\mathrm{m})$, well-preserved foraminifers were found in the clayey rocks underlying the Turonian clays; they form the Trochammina wetteri tumida - Verneuilinoides kansasensis Assemblage of the upper zone. Poorly preserved tests occur the underlying deposits of this section (borehole 2031), and they are characteristic of the assemblages of all seven borehole sections of the Upper Cenomanian.

The foraminifers in these sections indicate a constant advance of the Cenomanian transgression (lower and upper zones), resulting in basin deepening. The depth remained relatively moderate, however, and did not surpass the depths range characteristic of the modern shelf. This is indicated by the predominance of beds with coarse-grained, poorly preserved agglutinated tests. Along with the above-indicated forms, sparse secreted calcareous tests, which are dominated by genera of the Rotaliida and Buliminida orders occur in some interbeds, especially in the lower zone. In some of the sections, and within the lower part of the upper zone, mainly clayey beds occur, indicating a basin deepening with the ongoing Boreal transgression. Highly evolved forms of the Ataxophragmiida order, including tests of the genus Gaudryinopsis, are present in these beds. At precisely the same time, the foramini- fers developed that now form the Trochammina wetteri tumida - Verneuilinoides kansasensis Assemblage; the beds containing this assemblage form the upper zone of the same name (Tables $2,3)$.

In the deposits of the Late Cenomanian Uvatskian Horizon, seventeen foraminifer species and four subspecies were found; among them are ten species and four geographical subspecies (Plates I-IV) that were distinguished only recently (Podobina, 2012a,c). These species need further investigation so that the stratigraphical division of the upper Cenomanian can be detailed further, which is important as it contains economical hydrocarbon fields.

The investigation of the clayey cap-rocks that seal the hydrocarbons is not less significant. They form the overlying Turonian Kuznetsovskian Horizon that is present almost everywhere in Western Siberia. In this horizon, two foraminifer zones have been established: a (lower) Gaudryinopsis angustus Zone and an (upper) Pseudoclavulina hastata Zone, corresponding to the early and late Turonian, respectively. In the lowermost part of the Gaudryinopsis angustus Zone, beds with Hedbergella loetterlei are present where planktonic forms of the genus Hedbergella predominate. The Turonian species in the borehole sections (Plates V-VI) have previously been described (Podobina, 1975, 1989, 2000, 2009, 2012b).

The late Cenomanian-Turonian foraminifer assemblages of the West-Siberian and Canadian provinces have been compared, which reaffirmed their assignment to the common Arctic palaeobiogeographical realm. The comparison was carried out between West-Siberian foraminifer species and those from J. Wall's collection, along with species described by American and Canadian investigators (Tappan, 1962; Wall, 1967; McNeil, 1997). This comparison shows that Western Siberia and Canada have vicarious species, as well as geographical subspecies in common. In addition, the comparison enabled a detailed correlation of foraminifer zones and beds, and allowed to establish the precise age and stratigraphical position of the West-Siberian Cenomanian-Turonian stratigraphic units. 


\section{Acknowledgements}

The author acknowledges the workers of the Micropaleontological Laboratory of Tomsk State University for their contributions to the investigation and the processing of the manuscript.

I wish to express my gratitude to the anonymous reviewers for their valuable comments. Particularly the helpful comments, constructive criticism and important suggestions by anonymous Reviewer 2 are gratefully acknowledged and deeply appreciated.

I would also like to thank Doctor A.J. van Loon for his kind assistance and for detailed, thorough and very helpful contributions.

All figures in the plates were prepared by O.M. Lozovaya. The author appreciates her assistance.

All specimens depicted in the plates are stored in the Micropaleontological Department of the Paleontological Museum of Tomsk State University.

\section{References}

McNeil, D.H., 1997. New foraminifera from the Upper Cretaceous and Cenozoic of the Beaufort-Mackenzie basin of Arctic Canada. Cushman Foundation for Foraminiferal Research, Special Publication 35, 95 pp.

Nauss, A., 1947. Cretaceous microfossils of the Vermilion area, Alberta. Journal of Paleontology 21, 329-343.

Podobina, V.M., 1975. Foraminifery verkhnego mela i paleogena zapadnosibirskoy nizmennosti, ikh znacheniye dlya stratigrafii [The Upper Cretaceous and Palaeogene foraminifers of the Western Siberian plain and their significance for the stratigraphy]. Tomsk University Press, Tomsk, 264 pp., 40 pls. [in Russian].

Podobina, V.M., 1989. Foraminifery i zonl'naya stratigrafiya verkhnego mela Zapadnoy Sibiri [Foraminifers and zonal stratigraphy of the Upper Cretaceous in Western Siberia]. Tomsk University Press, Tomsk, 232 pp., 35 pls. [in Russian].

Podobina, V.M., 1995. Paleozoogeographic regionalization of Northern Hemisphere Late Cretaceous basin based on foraminifera. [In:] M.A. Kaminski, S. Geroch \& M.A. Gasinski (Eds): Proceedings of the $4^{\text {th }}$ International Workshop on Agglutinated Foraminifera. Grzybowski Foundation Special Publication 3, 239-247.

Podobina, V.M., 2000. Foraminifery i biostratigrafiya verkhnego mela Zapadnoy Sibiri [Upper Cretaceous foraminifers and biostratigraphy of Western Siberia]. NTL Press, Tomsk, 388 pp., 80 pls. [in Russian].

Podobina, V.M., 2009. Foraminifery, biostratigrafiya verkhnego mela i paleogena Zapadnoy Sibiri [Foraminifers, biostratigraphy of the Upper Cretaceous and Palaeogene of Western Siberia]. Tomsk State University Press, Tomsk, 432 pp., 73 pls. [in Russian].

Podobina, V.M., 2012a. Foraminifery, biostratigrafiya verkhnego senomana severnogo raiona Zapadnoy Sibiri [Upper Cenomanian foraminifers and biostratigraphy of the northern part of Western Siberia]. Vestnik
TGU [Bulletin of Tomsk State University] 362, 189-193, 3 pls. [in Russian].

Podobina, V.M., 2012b. Noviye svedeniya po biostratigraphii I foraminiferam Turona Zapadnoy Sibiri [Recent data on the Turonian biostratigraphy and foraminifers of Western Siberia]. Vestnik TGU [Bulletin of Tomsk State University] 364, 181-184, 3 pls. [in Russian].

Podobina, V.M., 2012c. Noviye svedeniya po foraminiferam i biostratigraphii verkhnego senomana severnogo raiona Zapadnoy Sibiri [New data on upper Cenomanian foraminifers and biostratigraphy of northern district of Western Siberia].Vestnik TGU [Bulletin of Tomsk State University] 361, 182-187, 3 pls. [in Russian].

Podobina, V.M. \& Tanachova, M.I., 1967. Stratigraphiya gazonosnykh verkhnemelovykh otlozheniy severo-vostochnykh raionov Zapadnosibirskoy nizmennosti [Stratigraphy of the Upper Cretaceous oil-bearing deposits of the north-eastern districts of the West-Siberian plain]. [In:] G.A. Selyatitskiy (Ed.): Noviye danniye po geologii i polieznym iskopayemym Zapadnoy Sibiri [Recent data on the geology and the mineral resources of Western Siberia] 2. Tomsk State University Press, Tomsk, 89-99 [in Russian].

Stelck, C. \& Wall, J., 1954. Kaskapau Foraminifera from Peace River Area of Western Canada. Research Council of Alberta 68, 6-38.

Stelck, C. \& Wall, J., 1955. Foraminifera of the Cenomanian Dunveganoceras Zone from Peace River Area of Western Canada. Research Council of Alberta 70, 6-79.

Subbotina, N.N. (Ed.), 1964. Foraminifery melovykh i paleogenovykh otlozheniy zapadnosibirskoy nizmennosti [Foraminifers of Cretaceous and Palaeogene deposits of the West-Siberian plain]. Nedra, Leningrad, 456 pp., 66 pls. [in Russian].

Tappan, H., 1962. Foraminifera from the Arctic slope of Alaska, Part 3, Cretaceous Foraminifera. United States Geological Survey Professional Paper 236 C, 91-209, 58 pls.

Vasilenko, L.V., 1997. Kompleksy foraminifer iz melovykh otlozheniy ostrova Belyi (Karskoye more) [Foraminifer assemblages from the Cretaceous deposits of Belyi island]. [In:] Stratigrafiya i paleontologiya Rossiyskoy Arktiki [Stratigraphy and palaeontology of the Russian Arctics]. VNII Okeanologiya, Sankt-Petersburg, 143-152 [in Russian].

Wall, J., 1967. Cretaceous Foraminifera of the Rocky Mountain foothills, Alberta. Research Council of Alberta 20, 185 pp.,15 pls.

Wall J., 1983. Jurassic and Cretaceous foraminiferal biostratigraphy in the Eastern Sverdrup basis, Canadian Arctic Archipelago. Canadian Petroleum Geology Bulletin 31, 246-281.

Zakharov, V.A., Beisel, A.L. \& Pokhialainen, V.P., 1989. Otkrytiye morskogo senomana na severe Sibiri [Discovery of marine Cenomanian in the north of Siberia]. Geologiya i Geophizika [Geology and Geophysics] 6, 10-13 [in Russian].

Manuscript received: 13 July 2012 Revision accepted: 15 July 2013 
Plate I. Fossils from the Late Cenomanian Uvatskian Horizon.

Note: Designations for plates I-III: $a=$ lateral view; $b=$ lateral or apertural view.

Fig. 1. Trochamminoides ivanetzi Podobina.

Holotype No. 3201. Western Siberia, Van-Eganskaya area, borehole 2031, depth 1,000.0 m.

Fig. 2. Labrospira rotunda Podobina.

Holotype No. 3202. Western Siberia, Van-Eganskaya area, borehole 2031, depth $945.0 \mathrm{~m}$.

Fig. 3. Haplophragmoides variabilis Podobina.

Holotype No. 3203. Western Siberia, Van-Eganskaya area, borehole 2031, depth 945.0 m. 


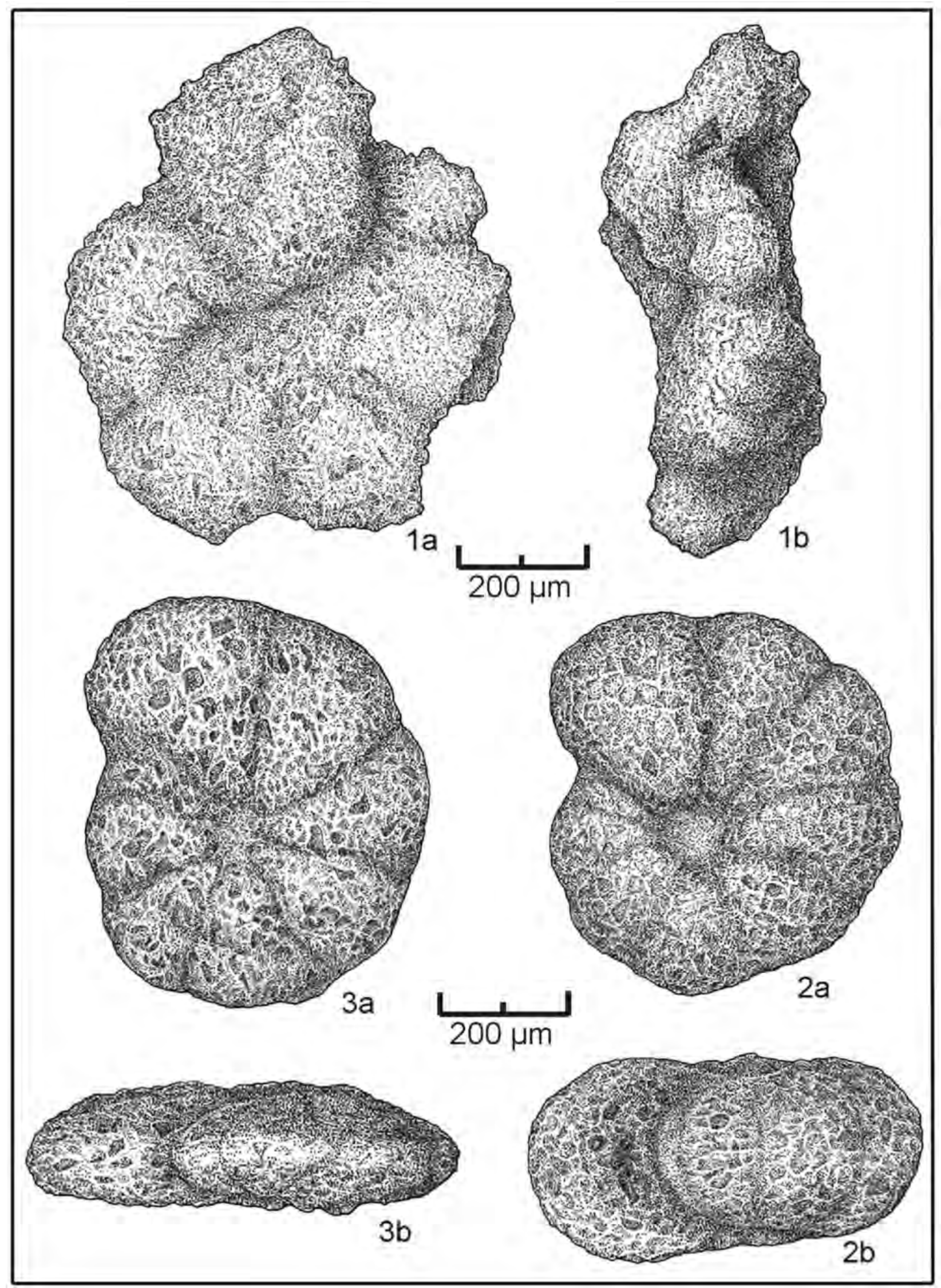


Plate II. Fossils from the Late Cenomanian Uvatskian Horizon.

Fig. 1. Ammobaculites wenonahae Tappan

Specimen No. 3205. Western Siberia, Van-Eganskaya area, borehole 2031, depth $945.0 \mathrm{~m}$.

Figs 2-3. Haplophragmium ivlevi Podobina.

Holotype No. 3209. Paratype No. 3209a. Western Siberia, Van-Eganskaya area, borehole 2031, depth $945.0 \mathrm{~m}$.

Figs 4, 6. Ammoscalaria senomanica Podobina.

Holotype No. 3208. Western Siberia, Van-Eganskaya area, borehole 2031, depth $945.0 \mathrm{~m}$.

Paratype No. 3208a. Western Siberia, Van-Eganskaya area, borehole 1002, depth $951.0 \mathrm{~m}$.

Fig. 5. Ammomarginulina sibirica Podobina.

Holotype No. 3206. Western Siberia, Van-Eganskaya area, borehole 1002, depth 951.0 m. 


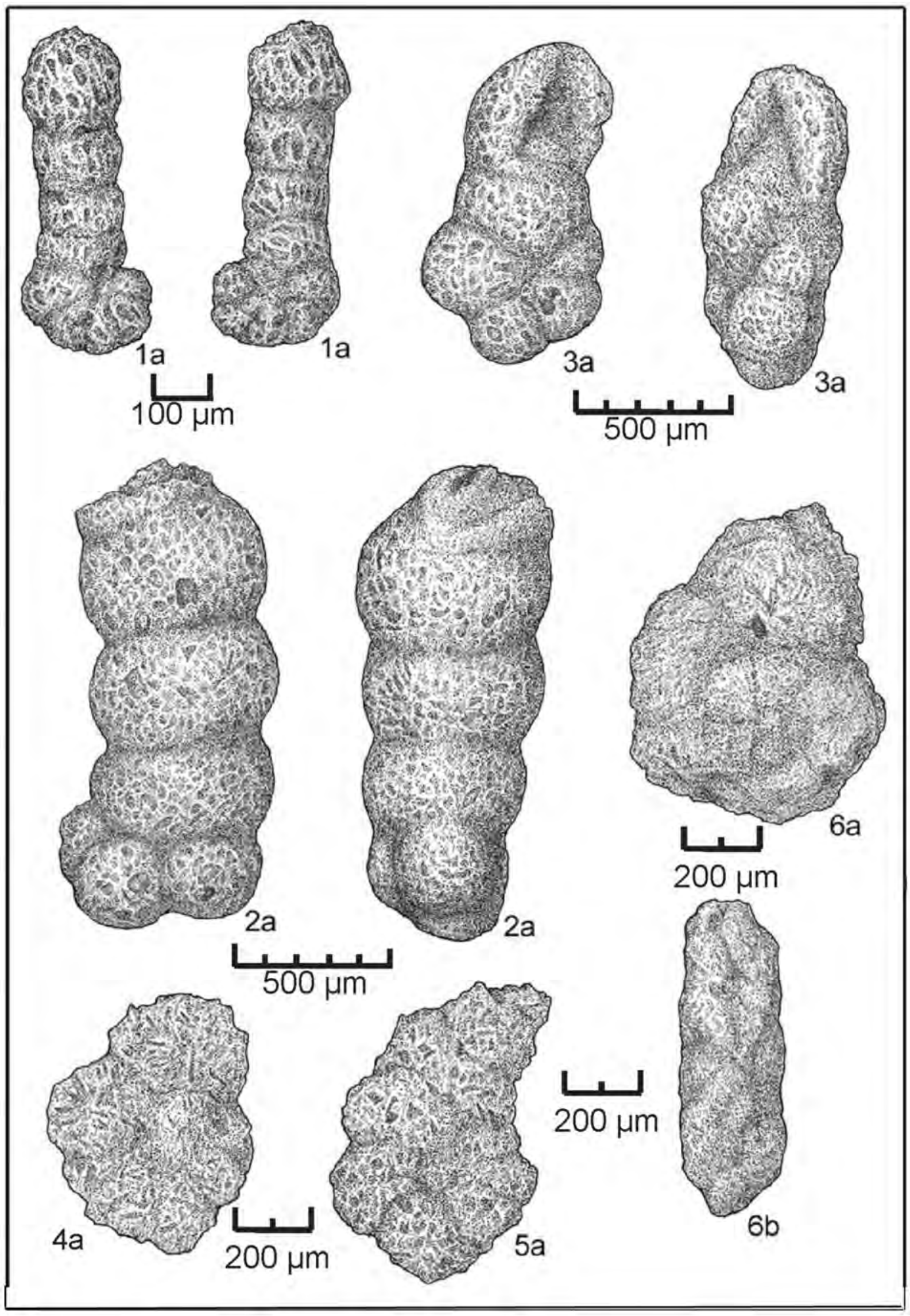


Plate III. Fossils from the Late Cenomanian Uvatskian Horizon.

Fig. 1. Flabellammina acuminata Podobina.

Holotype No. 3210. Western Siberia, Van-Eganskaya area, borehole 2010, depth $959.2 \mathrm{~m}$.

Fig. 2. Spiroplectammina longula Podobina.

Holotype No. 3213. Western Siberia, Van-Eganskaya area, borehole 2031, depth $945.0 \mathrm{~m}$. Fig. 3. Bolivinopsis perparvus Podobina.

Holotype No. 3215. Western Siberia, Van-Eganskaya area, borehole 2031, depth 945.0 m. 


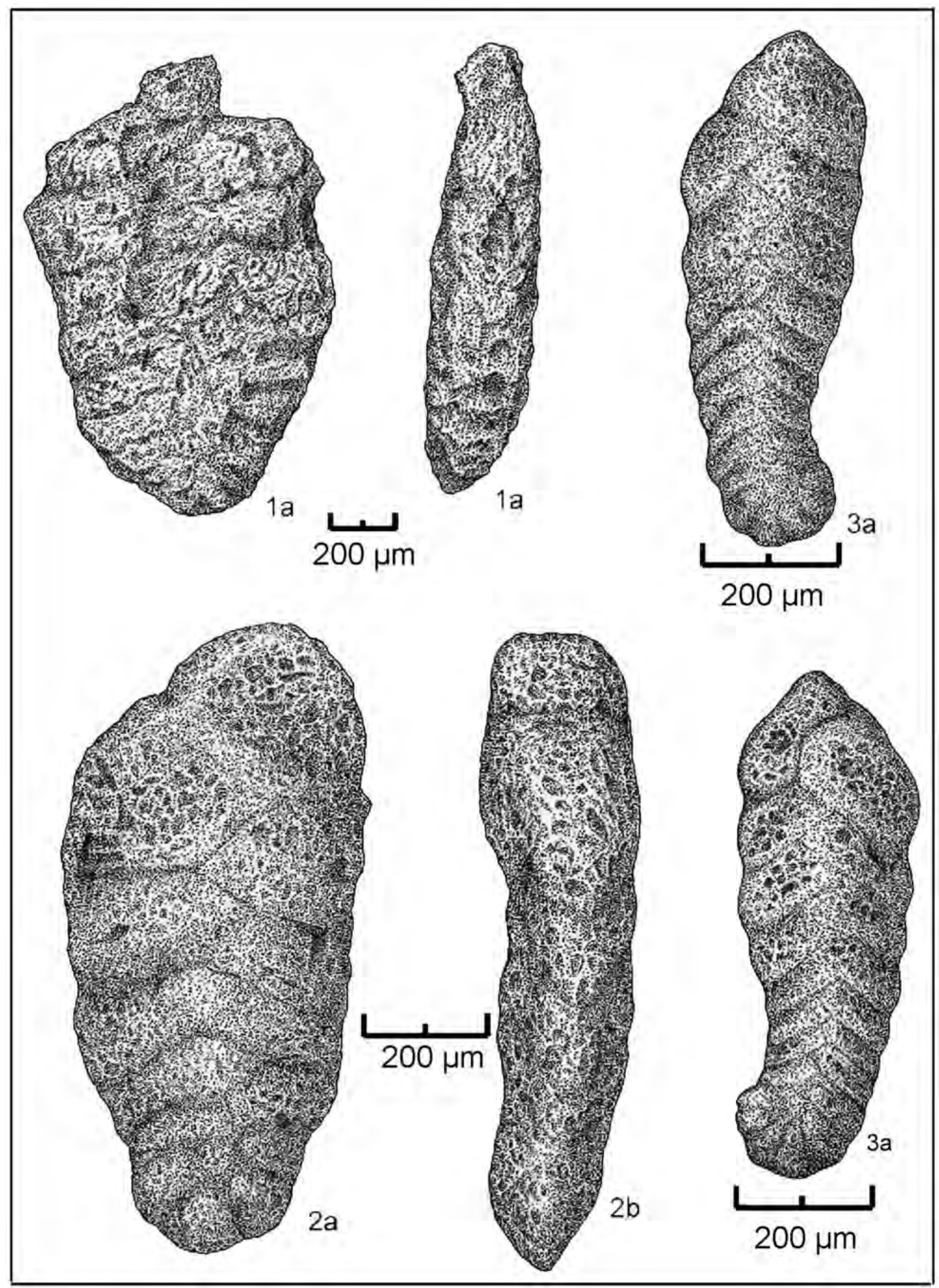


Plate IV. Fossils from the Late Cenomanian Uvatskian Horizon.

Figs. 2-4. Late Cenomanian geographical subspecies.

Designations: $a=$ lateral or dorsal view; $b=$ ventral view; $c=$ apertural view.

Figs. 1. Verneuilinoides kansasensis Loeblich et Tappan.

Specimen No. 3217. Western Siberia, Van-Eganskaya area, borehole 2031, depth $945.0 \mathrm{~m}$.

Fig. 2. Gaudryinopsis nanushukensis Tappan subsp. elongatus Podobina.

Subspecies holotype No. 3212. Western Siberia, Van-Eganskaya area, borehole 2010, depth $959.2 \mathrm{~m}$.

Fig. 3. Trochammina wetteri Stelck et Wall subsp. tumida Podobina.

Subspecies holotype No. 3218. Western Siberia, Van-Eganskaya area, borehole 2031, depth $945.0 \mathrm{~m}$. Fig. 4. Trochammina subbotinae Zaspelova subsp. mutabila Podobina.

Subspecies holotype No. 3220. Western Siberia, Van-Eganskaya area, borehole 2010, depth $959.2 \mathrm{~m}$. 


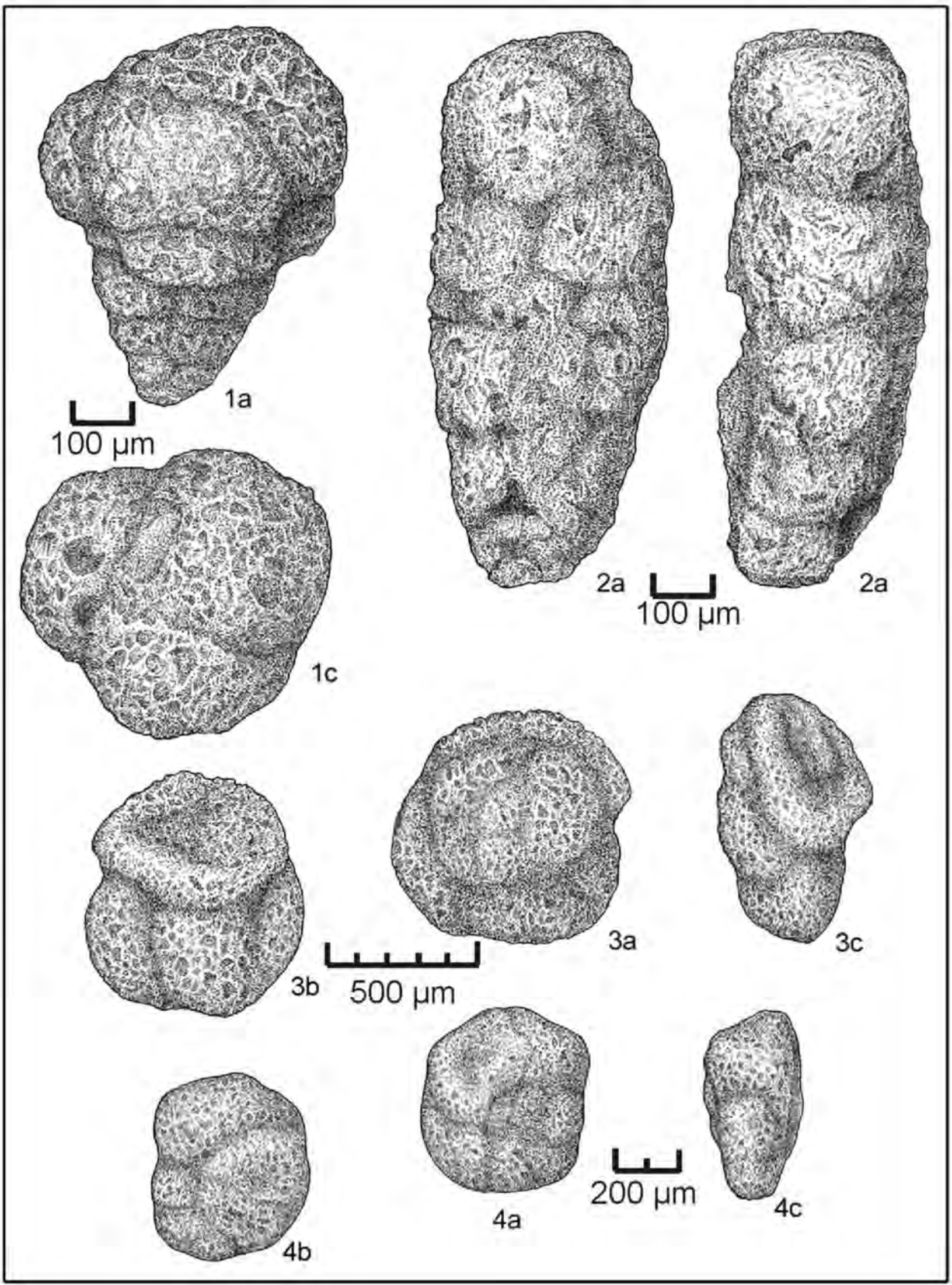


Plate V. Fossils from the Early Turonian, Kuznetsovskian Horizon.

Designations: $a=$ lateral or dorsal view; $b=$ lateral or apertural view; $c=$ ventral view .

Fig. 1. Lituotuba confusa (Zaspelova).

Specimen No. 308. Tomsk region, Novo-Vasyuganian key hole 1-r, depth interval 886.75-884.45 m.

Fig. 2. Lituotuba confusa (Zaspelova).

Specimen No. 310. Omsk region, Uyskian profile, borehole 20-k, depth $824.0 \mathrm{~m}$.

Fig. 3. Labrospira collyra (Nauss).

Specimen No. 145. Omsk region, Lavrino, borehole 13-k, depth interval 1,010.0-1,001.0 m.

Fig. 4. Haplophragmium incomprehensis (Ehremeeva).

Specimen No. 431. Tomsk region, Vasyuganian profile, borehole 1GK, depth interval 731.7- $722.1 \mathrm{~m}$.

Fig. 5. Ammomarginulina tuaevi (Zaspelova).

Specimen No. 437. Tyumen region, Tazovskaya area, borehole 3-r, depth interval 1,105.15-1,101.15 m.

Fig. 6. Ammomarginulina haplophragmoidaeformis (Balakhmatova).

Specimen No. 785. Tomsk region, Ambarskaya area, borehole 1-r, depth interval 918.56-915.16 m.

Fig. 7. Uvigerinammina manitobensis (Wickenden).

Specimen No. 444. Tyumen region, Tazovskaya area, borehole 13-r, depth interval 1,140.0-1,135.57 m.

Fig. 8. Trochammina subbotinae Zaspelova.

Specimen No. 206. Tyumen region, Tazovskaya area, borehole 25-r, depth interval 1,199.7-1,195.8 m.

Fig. 9. Gaudryinopsis angustus Podobina.

Specimen No. 382a. Tomsk region, Ambarskaya area, borehole 1-r, depth interval 918.56-915.16 m. 


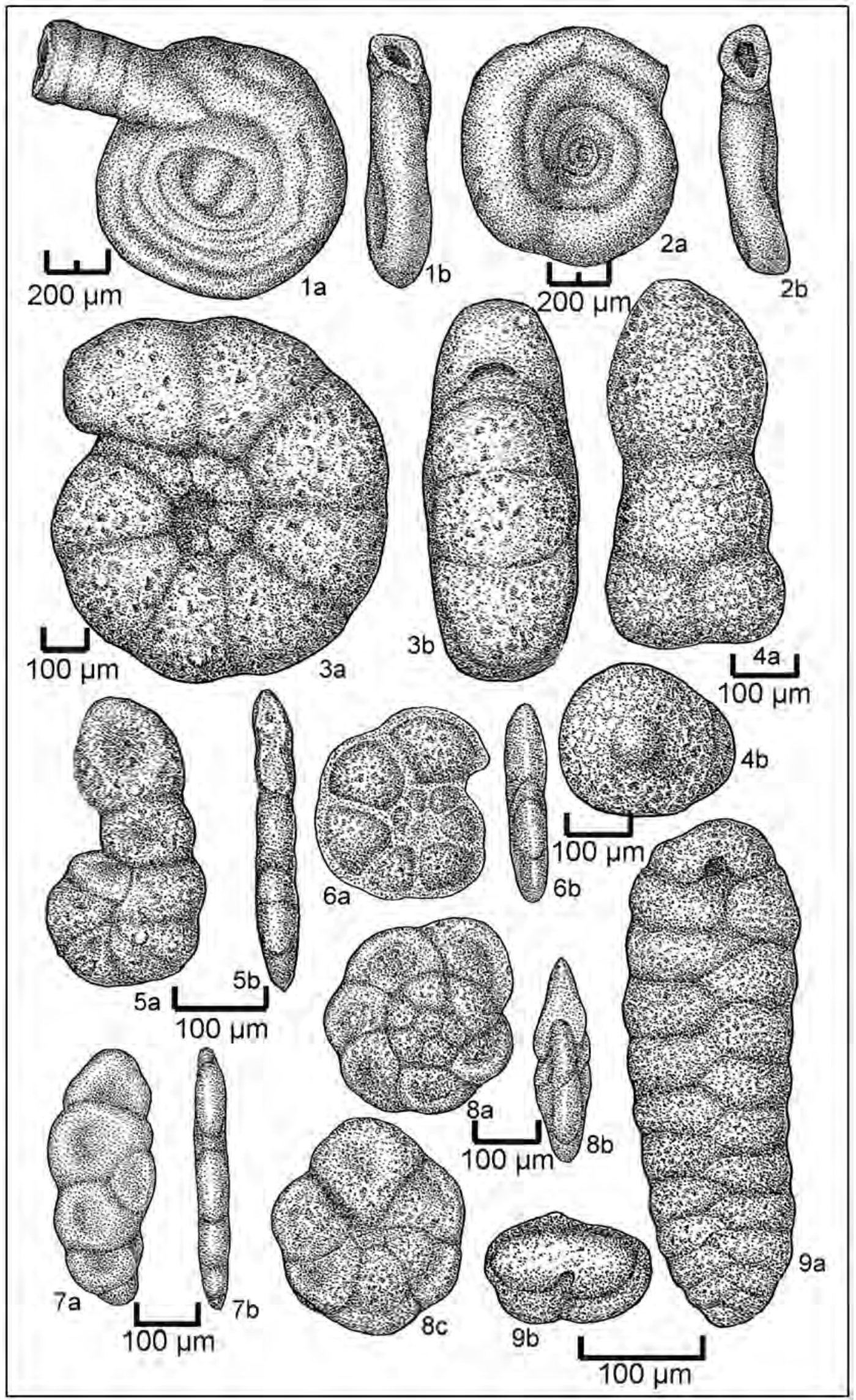


Plate VI. Fossils from the Late Turonian, Kuznetsovskian Horizon.

Designations: $a=$ lateral or dorsal view; $b$ = apertural view; $c=$ ventral view.

Fig. 1. Haplophragmoides rota Nauss subsp. sibiricus Zaspelova.

Specimen No. 167. Omsk region, Uyskian profile, borehole 20-k, depth $880.0 \mathrm{~m}$.

Fig. 2. Haplophragmoides crickmayi Stelck et Wall.

Specimen No. 171. Tomsk region, Vasyuganian profile, borehole 1GK, depth interval 731.0- $722.1 \mathrm{~m}$.

Fig. 3. Ammoscalaria antis Podobina.

Specimen No. 797. Tomsk region, Festivalnaya area, borehole 25, depth interval 838.0-830.0 m.

Fig. 4. Textularia anceps Reuss.

Specimen No. 213a. Tyumen region, Leushinskaya borehole 1-r, depth $771.4 \mathrm{~m}$.

Fig. 5. Pseudoclavulina hastata (Cushman).

Specimen No. 280. Omsk region, Uyskian profile, borehole 20-k, depth $830.0 \mathrm{~m}$.

Fig. 6. Pseudoclavulina hastata (Cushman).

Specimen No. 281. Omsk region, Uyskian profile, borehole 20-k, depth $830.0 \mathrm{~m}$.

Fig. 7. Trochammina arguta Podobina.

Specimen No. 250. Omsk region, Tara key hole 1-r, depth interval 858.2-846.6 m. 


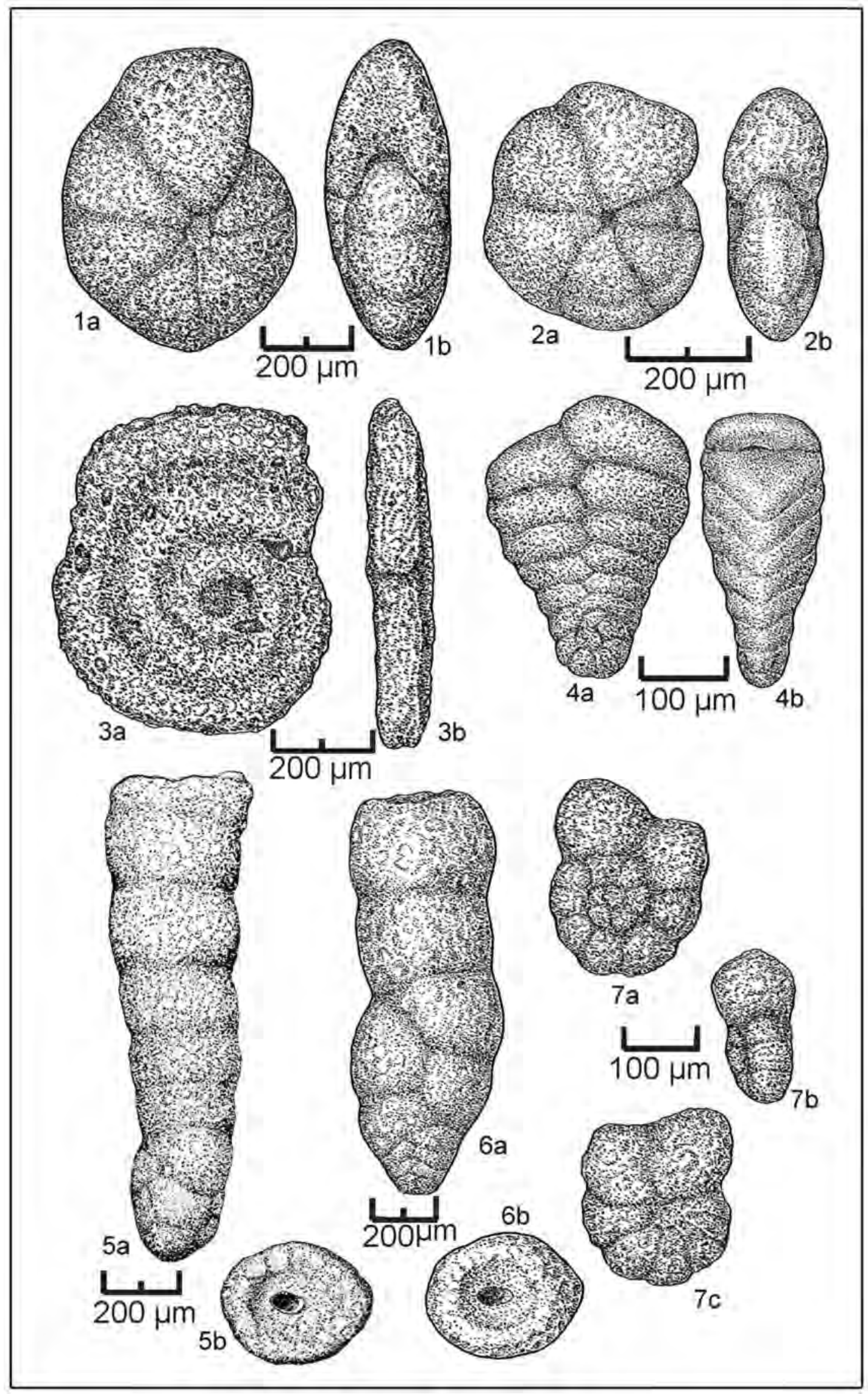

